\title{
Program Eco-Pesantren Sebagai Model Pendidikan Lingkungan Hidup
}

\author{
Sri Rahayu Pudjiastuti ${ }^{1 *}$, Herinto Sidik Iriansyah ${ }^{2}$, Yuliwati $^{3}$ \\ ${ }^{1}$ Magister Pendidikan Pancasila dan Kewarganegaraan, STKIP Arrahmaniyah Depok \\ ${ }^{2}$ Pendidikan Pancasila dan Kewarganegaraan, STKIP Kusuma Negara \\ ${ }^{3}$ Pendidikan Bahasa Inggris, STKIP Kusuma Negara \\ *srirahayu@ stkip-arrahmaniyah.ac.id
}

\begin{abstract}
Abstrak
Tujuan kegiatan pengabdian kepada masyarakat ini adalah membangun program ecopesantren, sebagai salah satu bentuk pendidikan lingkungan hidup berbasis pondok pesantren. Metode pelaksanaan untuk pencapaian target program eco-pesantren adalah: pelaksanaan penyuluhan dan pelatihan. Pelaksanan program dilakukan dengan beberapa tahapan, yaitu: (1) pengenalan program eco-pesantren dan persiapan pelaksanaan program; (2) penyuluhan dan pelatihan; (3) praktek ramah lingkungan oleh warga pondok pesantren; dan (4) pelaksanaan evaluasi program. Hasil kegiatan menunjukkan bahwa: tingkat pemahaman tentang pengelolaan sanitasi berkategori baik, dimana tingkat pemahaman meningkat dengan skor 78 (sedang), sedangkan untuk aspek pengelolaan sampah juga memiliki skor 75 (sedang). Pemahaman tentang pengelolaan lingkungan pondok pesantren dengan skor 70 (sedang) artinya peserta pelatihan sudah memahami beberapa cara-cara mengelola taman, menjaga kebersihan toilet, kebersihan selokan, dan mengelola sarana lain yang ada di pondok pesantren. Kesimpulan kegiatan ini adalah: (1) program pengabdian kepada masyarakat dapat dilaksanakan dan direspon dengan baik oleh warga pondok pesantren Nurul Huda, Kampung Rumbut, Kelurahan Pasir Gunung Selatan, Cimanggis, Depok; (2) program pengabdian kepada masyarakat ini sangat bermanfaat bagi warga pondok pesantren, dan institusi pelaksana karena dapat menjadi media transfer ilmu pengetahuan dan teknologi khususnya pelestarian lingkungan hidup di Pondok Pesantren Nurul Huda untuk menuju eco-pesantren.
\end{abstract}

Kata kunci: eco-pesantren, pendidikan lingkungan hidup.

Dikirim: 21 April 2021

Direvisi: 26 April 2021

Diterima: 28 April 2021

\section{PENDAHULUAN}

Program eco-pesantren sebagai model pendidikan lingkungan hidup yang diterapkan di pondok pesantren sudah digagas bersama Kementerian Agama Republik Indonesia pada tanggal 5 sampai tanggal 6 Maret 2008. Eco-pesantren sebagai salah satu bentuk pendidikan lingkungan hidup khas Indonesia berbasis pondok pesantren. Istilah eco-pesantren pertama kali diperkenalkan pada pertemuan "moeslem seven year action plan for climate change" di Istambul Turki pada awal Juni 2009. Eco-pesantren berarti sebuah institusi pendidikan Islam (pesantren) yang mempunyai penekanan pada aktivitas yang tanggap terhadap kelestarian lingkungan hidup.

Menjaga kelestarian alam, tidak hanya didorong oleh kesadaran bahwa bencana akan datang jika alam tak dijaga. Tetapi juga sebagai bentuk ketaatan seorang muslim. Karena Allah memerintah kita agar berbuat baik, maka berbuat baik terhadap alam adalah juga bentuk ketaatan. "Islam adalah agama yang memerintah 
pemeluknya untuk berbuat baik. Tak hanya berbuat baik karena Allah (hablum minallah) dan berbuat baik bagi sesama manusia (hablum minannas), Islam juga memerintah agar muslim berbuat baik terhadap alam (hablum minal alam),"

Komitmen pesantren dalam menamkan nilai-nilai ajaran Islam direalisasikan dengan berbagai macam bentuk pelayanan keagamaan, seperti mengadakan pendidikan diniyah, menyelenggarakan PKBM (Pusat Kegiatan Belajar Masyarakat), melakukan dakwah pada masyarakat melalui forum pengajian, memberikan penyuluhan pada masyarakat, dan berbagai macam penanaman nilainilai yang terkandung dalam ajaran Islam. Pesantren terlibat aktif dalam pengkajian keagamaan dan pola-pola sejenis yang dikembangkan dimasyarakat. Kegiatan pesantren ini merupakan benih sangat potensial dalam upaya pengembangan dan pemberdayaan masyarakat. Peran pesantren terlibat secara langsung dalam kegiatan yang lebih substansial dan memfokuskan diri pada kebutuhan riil masyarakat, seperti pengembangan ekonomi, pelestarian lingkungan, dan penggunaan teknologi alternatif (A'la, 2006: 3-4).

Adanya nilai normatif ajaran Islam sebagai sebuah doktrin secara tegas melarang kepada umat manusia untuk merusak lingkungan sudah sering di sampaikan oleh para ustaz dalam pengajian-pengajian. Berbagai upaya untuk menanamkan nilai-nilai ajaran Islam tentang kepedulian terhadap lingkungan sekitar pesantren, khususnya dalam menyadarkan pada semua santri supaya selalu mengingat doktrin ajaran agama tersebut ada beberapa ayat al-Qur'an yang sengaja dipasang sebagai pengingat betapa menjaga lingkungan dan kelestariannya sangat penting. Seperti pada surat. Al-A'raf [7]: 85 yang dipasang di samping aula utama pesantren:

Dan janganlah kamu membuat kerusakan di muka bumi sesudah Tuhan memperbaikinya. Yang demikian itu lebih baik bagimu jika betul-betul kamu orang-orang yang beriman (QS. al-A'raf [7]: 85) Jika dipahami secara mendalam, ayat tersebut secara tegas melarang secara umum kepada seluruh umat manusia, dan secara khusus kepada seluruh santri di pesantren, membuat kerusakan atau merusak lingkungan yang telah dibuat dan diperbaiki oleh Allah SWT. Doktrin tersebut sekaligus memberikan perintah kepada umat manusia untuk menjaga dan merawat lingkungan yang telah dibuat oleh Allah dengan baik dan penuh tanggung jawab. Kemudian, dalam pemanfaatan alam, di dalam ajaran Islam juga dijelaskan secara tegas. Sebagaimana firman Allah dalam QS. Luqman [31] ayat 20:

"Tidakkah kamu perhatikan sesungguhnya Allah telah menundukkan untuk (kepentingan) mu apa yang ada di langit dan apa yang ada di bumi dan menyempurnakan untukmu nikmat-Nya lahir dan batin" (QS. Lukman [31]: 20). Ayat tersebut dengan tegas menyatakan bahwa Allah telah memberikan kepada umat manusia segala apa yang ada di langit dan di bumi. Dalam ayat ini terkandung maksud bahwa Allah telah memberikan segala bentuk kenikmatan yang dapat diperoleh seluruh manusia, hanya saja manusia harus bertanggung jawab terhadap semua nikmat yang telah diberikan Allah. Tanggung jawab itu merupakan bentuk syukur atas berbagai nikmat yang telah diberikan Allah. Barang siapa yang mensyukuri nikmat yang telah diberikan Allah, maka Allah akan menambahkan nikmat kepada hamba tersebut, dan sebaliknya, barang siapa yang mensyukuri nikmat yang telah diberikan Allah, yaitu tidak bertanggung terhadap nikmat yang telah diberikan maka mereka termasuk golongan orang-orang yang merugi dan akan mendapat siksanya. 
Pemeliharaan lingkungan bukanlah sekadar estetika (keindahan) semata namun lebih pada implementasi tujuan diberlakukannya nilai-nilai ajaran Islam. Yusuf Qardhawi menjelaskan bahwa pemeliharaan lingkungan termasuk dalam tujuan pemberlakuan syariah agama sebagaimana konsepsi Imam Al Syatibi berkaitan tujuan pemberlakuan syariat Islam, (Qardhawi, 2001, 39).

Dalam lingkungan pesantren Nurul Huda hidup bersih tersebut dimulai dari diri masyarakat pesantren sendiri terutama para guru (ustaz) dalam posisinya sebagai pendidik. Sebagaimana ungkapan dari guru yang berarti digugu dan ditiru. Bagaimana anak didik akan meniru gurunya, kalau guru membuang sampah disembarang tempat atau merokok dan membuang puntungnya di mana saja, maka untuk menciptakan lingkungan bersih dalam lingkungan pesantren memandang harus dimulai dari guru sebagai pendidik. Selain keteladanan juga ditarapkan beberapa peraturan yang lebih spesifik untuk ditaati bersama-sama di pesantren. Bentuk kegiatan tersebut adalah: (1) Adanya tata tertib santri dan guru agar menjaga kebersihan lingkungan pesantren. Bentuk dari kegiatannya sendiri yaitu pesantren membuat tata tertib yang isinya bagi semua warga yang tinggal di pesantren wajib melaksanakan dan menjaga lingkungan yang bersih dan sehat. (2) Adanya bentuk kegiatan yang disebut dengan piket lingkungan dan jadwal piket. Kegiatan "piket lingkungan" menurut ketua bidang kebersihan dan kesehatan, adalah kegiatan yang dilaksanakan setiap hari, di mana para santri ditugaskan untuk melakukan kegiatan bersih-bersih lingkungan pesantren pada setiap pagi dan sore dan kegiatan bersih lingkungan yang bersifat kolektif, artinya pada setiap seminggu sekali seluruh penghuni pesantren wajib mengikuti kerja bakti dalam rangka membersihkan lingkungan sekitar. Kegiatan piket lingkungan ini sendiri adalah kegiatan bersihbersih lingkungan sekitar pesantren agar bersih dan nyaman, di samping juga untuk selalu menyiram tanaman yang ada di halaman pesantren agar tetap asri dan indah.

(3) Penerapan sanksi bagi warga santri yang tidak melaksanakan dan mendukung terciptanya lingkungan sekolah yang bersih dan sehat. Perilaku yang menunjukkan kearifan lokal juga ditunjukkan oleh para santri di lingkungan pondok yaitu dengan adanya pemeliharaan lingkungan sekitar pesantren dengan menata pertamanan, melakukan kegiatan kerja bakti membersihkan lingkungan, baik dalam bentuk piket, maupun program kerja bakti mingguan. Salah satu upaya pesantren kami dalam menanggulangi kerusakan lingkungan adalah dengan mengadakan ecopesantren, yaitu dengan mengadakan kegiatan penanaman pohon (Wawancara dengan Ketua Lingkungan di Pesantren Nurul Huda).

Di samping penghayatan dari doktrin ajaran Islam, dalam rangka merespon permasalahan lingkungan di sekitar pesantren, di pesantren Nurul Huda membentuk kesadaran santri yang sudah diwujudkan dalam bentuk selalu menaati peraturanperaturan yang diterapkan oleh pesantren terkait menjaga dan melestarikan lingkungan sekitar, mengadakan program penghijauan di sekitar pesantren sebagaimana yang dijelaskan di atas, yaitu dengan menumbuhkan kesadaran santri pada kesadarn menanam pohon, atau yang dikenal dengan istilah eco-pesantren.

Memberikan penyuluhan pada masyarakat, dan berbagai macam penanaman nilai-nilai yang terkandung dalam ajaran Islam. Pesantren terlibat aktif dalam pengkajian keagamaan dan pola-pola sejenis yang dikembangkan dimasyarakat. Kegiatan pesantren ini merupakan benih sangat potensial dalam upaya pengembangan dan pemberdayaan masyarakat. Peran pesantren terlibat secara langsung dalam kegiatan yang lebih substansial dan memfokuskan diri pada 
kebutuhan riil masyarakat, seperti pengembangan ekonomi, pelestarian lingkungan, dan penggunaan teknologi alternatif (A'la, 2006: 3-4).

Tucker \& Grim (2003: 85) mengatakan bahwa "agama memiliki lima resep dasar untuk menyelamatkan lingkungan: (1) referensi atau keyakinan yang dapat diperoleh dari teks-teks (kitab suci) dan kepercayaan yang umat manusia yakini. (2) respek, penghargaan kepada semua makhluk hidup yang diajarkan oleh agama sebagai makhluk Tuhan. (3) restain, kemampuan untuk mengelola dan mengontrol sesuatu supaya penggunaannya tidak mubazir. (4) redistribustion, kemampuan untuk menyebarkan kekayaan, kegembiraan, dan kebersamaan melalui langkah dermawan, misalnya zakat dan Infak. (5) responsibility, sikap bertanggung jawab dalam merawat kondisi lingkungan dan alam sekitar.

Pendapat tersebut sudah sejalan dengan konsep eco-pesantren. Oleh karena itu melalui program eco-pesantren ini diharapkan selain dapat menggugah kesadaran umat Islam untuk lebih memahami dan peduli terhadap kondisi lingkungannya, dan juga diharapkan dapat melakukan penggalian dan pengkajian secara komprehensif tentang konsep Islam yang berkaitan dengan lingkungan serta implementasinya. Dengan bentuk ikhtiar ini akan menjadikan pondok pesantren sebagai pusat pembelajaran lingkungan bagi masyarakat. Dengan adanya program eco-pesantren yang dilaksanakan pada pesantren Nurul Huda Cimanggis Depok, dengan berbagai macam bentuk kegiatan penanaman pohon, penghijauan, menunjukkan bahwa pesantren Nurul Huda sudah memiliki respon positif dalam rangka mewujudkan perannya dalam membentuk kesadaran dan kepedulian pada pelestarian lingkungan hidup, khususnya di wilayah pesantren.

\section{METODE PELAKSANAAN}

Metode pelaksanaan pengabdian masyarakat dengan program eco-pesantren menggunakan metode penyuluhan dan pelatihan dimana lingkungan alamiah sebagai sumber data (Pudjiastuti, 2019). Kegiatan yang dilakukan melibatkan partisipasi aktif warga pondok pesantren, implementasi kebijakan eco-pesantren, kegiatan lingkungan berbasis partisipatif, pengelolaan sarana pendukung ramah lingkungan, dan melihat respon perilaku warga pondok pesantren Nurul Huda Cimanggis Depok dalam pengelolaan program eco-pesantren. Kegiaatan dilaksanakan pada tanggal 14 Januari 2021. Pelaksanan kegiatan dilakukan dengan beberapa tahapan, yaitu: (1) pengenalan program eco-pesantren dan persiapan pelaksanaan program; (2) penyuluhan dan pelatihan; (3) praktek ramah lingkungan oleh warga pondok pesantren, dan (4) pelaksanaan evaluasi program. Pelaksanaan kegiatan Lingkungan berbasis partisipatif oleh warga pondok pesantren, meliputi: (a). pemanfaatan lahan dan fasilitas pesantren sesuai kaidah-kaidah perlindungan dan pengelolaan lingkungan hidup seperti adanya taman disetiap kelas, apotek hidup, green house, pembibitan tanaman, kolam ikan dan pengelolaan sampah. (b). pengembangan kegiatan dalam upaya perlindungan dan pengelolaan lingkungan hidup dengan memasukan pemahaman lingkungan hidup bagi santri seperti: kepedulian terhadap lingkungan dengan mengelola sampah dengan daur ulang ataupun pengomposan. Menciptakan kebersamaan warga pesantren dan kondisi bejar yang lebih nyaman dan kondusif, menjadikan tempat pembelajaran nilai-nilai pemeliharaan dan pengelolaan lingkungan hidup yang baik dan benar bagi warga pondok pesantren, meningkatkan upaya perlindungan dan pengelolaan lingkungan 
hidup melalui kegiatan pengendalian/pelestarian lingkungan pesantren. Pelaksanaan evaluasi dilakukan dua kali, yaitu: pada akhir penyuluhan dan pelatihan dilakukan untuk mengetahui tingkat pemahaman materi yang disampaikan, dan pada akhir praktek ramah lingkungan. Evaluasi ini bertujuan untuk melihat seberapa banyak program yang direspon oleh warga pondok pesantren.

\section{HASIL DAN PEMBAHASAN}

\section{Penyuluhan Eco-Pesantren}

Beberapa materi penyuluhan dan pelatihan yang diberikan kepada santri untuk pengembangan dan pengelolaan sarana pendukung pesantren yang ramah lingkungan dapat dilihat pada Tabel 1 .

Tabel 1. Materi Penyuluhan Program Eco-Pesantren

\begin{tabular}{|c|c|c|c|}
\hline Tujuan & Kegiatan & Sasaran & Output \\
\hline \multirow{4}{*}{$\begin{array}{l}\text { Memanfaatkan } \\
\text { sarana pendukung } \\
\text { sebagai media } \\
\text { pembelajaran }\end{array}$} & $\begin{array}{l}\text { Pemanfaatan "green } \\
\text { hous" }\end{array}$ & Santri & $\begin{array}{l}\text { Santri dapat } \\
\text { memanfaatkan rumah } \\
\text { kaca }\end{array}$ \\
\hline & $\begin{array}{l}\text { Pemanfaatan } \\
\text { pohon/kebun }\end{array}$ & Santri & $\begin{array}{l}\text { Santri dapat menanam } \\
\text { dan mencangkok dengan } \\
\text { baik }\end{array}$ \\
\hline & Pembibitan & Santri & $\begin{array}{l}\text { Santri dapat melakukan } \\
\text { pembibitan tanaman }\end{array}$ \\
\hline & $\begin{array}{l}\text { Pemeliharaan dan } \\
\text { pengaturan pohon } \\
\text { peneduh/penghijauan }\end{array}$ & $\begin{array}{l}\text { Warga } \\
\text { pondok } \\
\text { pesantren }\end{array}$ & $\begin{array}{l}\text { Lingkungan pesantren } \\
\text { yang teduh dan rindang }\end{array}$ \\
\hline \multirow[t]{2}{*}{$\begin{array}{l}\text { Mengelola } \\
\text { fasilitas sanitasi }\end{array}$} & $\begin{array}{l}\text { Membuat jadwal } \\
\text { kegiatan pengelolaan } \\
\text { sanitasi }\end{array}$ & $\begin{array}{l}\text { Warga } \\
\text { pondok } \\
\text { pesantren }\end{array}$ & $\begin{array}{l}\text { Adanya jadwal piket } \\
\text { pengelolaan sanitasi }\end{array}$ \\
\hline & $\begin{array}{l}\text { Pengadaan bong untuk } \\
\text { air bersih di tiap } \\
\text { halaman kelas dan } \\
\text { pintu masuk Pondok } \\
\text { Pesantren }\end{array}$ & $\begin{array}{l}\text { Warga } \\
\text { pondok } \\
\text { pesantren }\end{array}$ & $\begin{array}{l}\text { Tersedianya tempat cuci } \\
\text { tangan bagi tamu dan } \\
\text { Warga pondok pesantren }\end{array}$ \\
\hline \multirow[t]{2}{*}{$\begin{array}{l}\text { Mengelola } \\
\text { sampah }\end{array}$} & $\begin{array}{l}\text { Menyediakan tempat } \\
\text { sampah }\end{array}$ & $\begin{array}{l}\text { Warga } \\
\text { pondok } \\
\text { pesantren }\end{array}$ & $\begin{array}{l}\text { Tersedianya tempat } \\
\text { sampah di setiap halaman } \\
\text { depan kelas }\end{array}$ \\
\hline & $\begin{array}{l}\text { Menyediakan tempat } \\
\text { penampungan sampah } \\
\text { sementara }\end{array}$ & $\begin{array}{l}\text { Warga } \\
\text { pondok } \\
\text { pesantren }\end{array}$ & $\begin{array}{l}\text { Tersedianya bak sampah } \\
\text { penampungan sementara }\end{array}$ \\
\hline
\end{tabular}

\section{Pengelolaan Lingkungan Pesantren (Tempat Belajar dan Taman Pesantren)}

Lingkungan pesantren yang bersih dan sehat tidak hanya di dalam kelas tetapi juga di luar kelas, seperti di halaman pesantren, kantin dan sarana olah raga. Halaman pesantren selain di tata keindahannya, juga perlu memperhatikan persyaratan kesehatan. Halaman pesantren yang tidak sehat dapat menimbulkan berbagai macam penyakit sehingga menimbulkan rasa tidak nyaman bagi semua warga pondok pesantren. Areal halaman Pondok Pesantren Nurul Huda terbagi menjadi 2, yaitu halaman yang digunakan untuk aktivitas sekolah dan taman. Halaman 
aktivitas digunakan untuk olahraga, upacara, bermain, dan kegiatan ektrakulikuler lainnya. Dengan ditutup bagian halaman (paving) diharapkan halaman tidak becek ketika hujan datang namun resapan air tetap terjaga serta mengurangi debu di musim kemarau. Disisi lain, untuk taman telah ditanami tumbuhan peneduh dan bunga-bunga untuk menciptakan suasana yang nyaman dan asri. Perawatan halaman ini dilakukan oleh para santri, dan para pengasuh melalui pengawasan Tim eco-pesantren dengan cara menyapu, memungut sampah, dan menyiram tanaman.

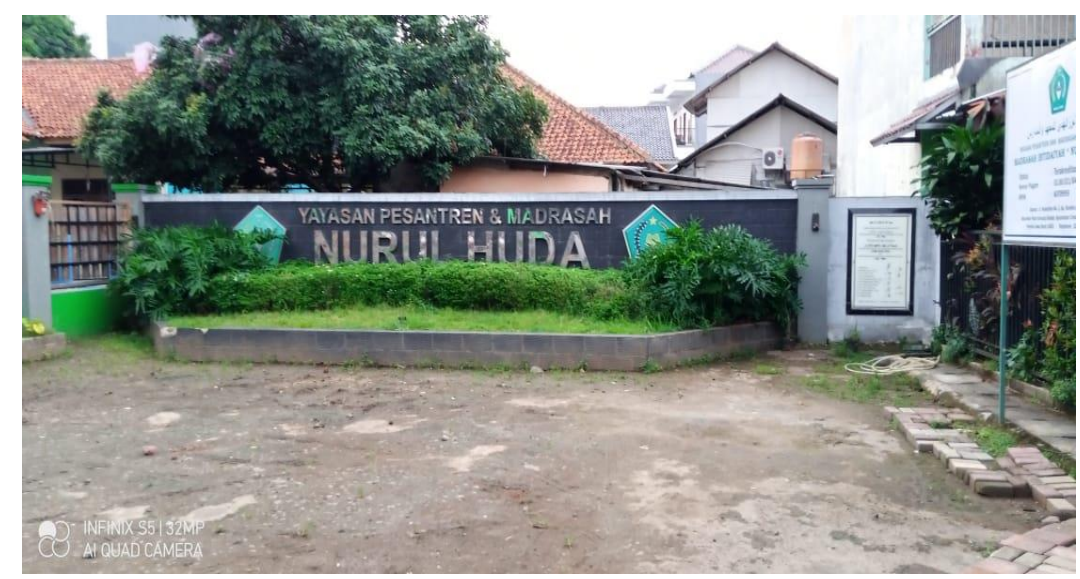

Gambar 1. Taman Pesantren Nurul Huda

\section{Perawatan Sanitasi}

Sanitasi merupakan komponen yang sangat penting dalam kehidupan lingkungan pesantren, kebersihan disemua sisi sangatlah penting untuk diperhatikan, seperti: pelayanan MCK di pondok pesantren Nurul Huda, dimana sarana ini tersedia sebanyak 50 MCK (20 santri putri, 20 santri putra dan 10 di sekolah mulai dari RA, MI, MTs dan MA serta khusus untuk guru). Ketersediaan sarana ini sudah cukup untuk memenuhi kebutuhan waraga pondok pesantren, sedangkan saluran pembuangan air yang terdapat disekeliling pesantren mendapatkan perawatan secara berkala, terlebih menjelang musim hujan. Perawatan kamar mandi dilakukan oleh para santri atas bimbingan ustad dan ustazah agar selalu terjaga kebersihannya. Sedangkan perawatan saluran sebulan sekali diadakan kegiatan minggu bersih agar kondisi selokan air lancar untuk pembuangan. Kegiatan ini untuk menjaga agar pondok pesantren selalu tetap bersih dan sehat, termasuk membiasakan warga pesantren berperilaku hidup sehat. Notoadmodjo (2010) menjelaskan bahwa melalui perilaku hidup sehat diharapkan masyarakat dapat mengenali dan mengatasi masalah sendiri dan dapat menerapkan cara-cara hidup sehat dengan menjaga, memelihara dan meningkatkan kesehatannya dengan memperhatikan lingkungan sekitarnya. Pudjiastuti (2020) dan Pudjiastuti \& Hadi (2020) menjelaskan manfaat mengembangkan perilaku sehat pada santri akan memiliki pola hidup sehat di kemudian hari saat kembali pada keluarga dan masyarakat. Artinya santri yang terbiasa dengan perilaku hidup sehat tidak mudah hilang pada saat mereka kembali pada keluarga dan masyarakat. 


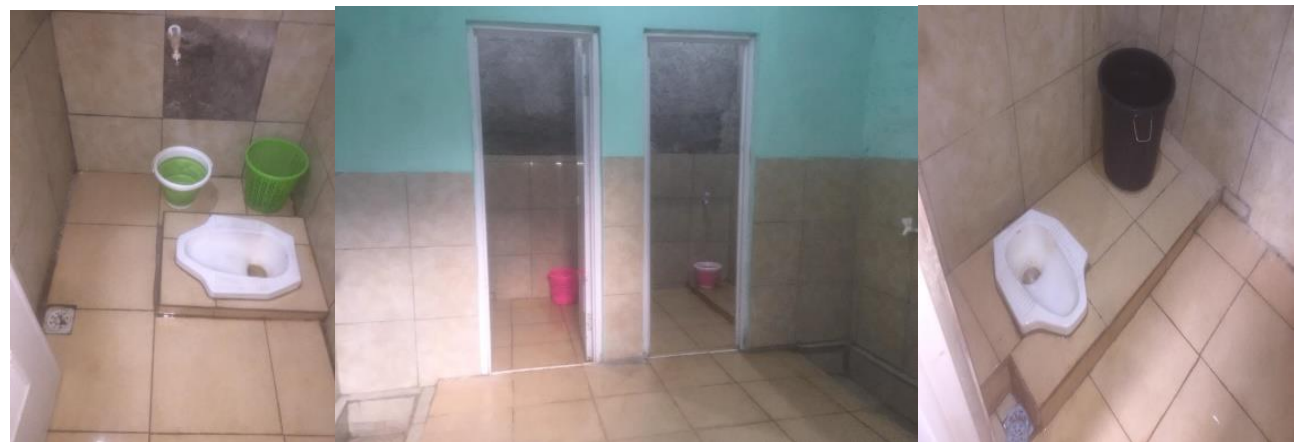

Gambar 2. Sanitasi pelayanan MCK Santri

\section{Pengelolaan Sampah di Pondok Pesantren}

Pengelolaan sampah di pesantren agar berlangsung dengan baik dan mencapai tujuan yang diinginkan, maka setiap kegiatan pengelolaan sampah harus mengikuti cara-cara yang baik dan benar. Pengelolaan sampah sangat penting di sekolah, prinsipnya semakin sedikit dan semakin dekat sampah dikelola dari sumbernya, maka pengelolaannya akan semakin mudah dan baik, serta lingkungan yang terkena dampak juga semakin sedikit.

Pada umumnya santri belum mempunyai kebiasaan hidup bersih. Kebiasaan yang ada justru membuang sampah di sungai/got, pekarangan orang lain, tanah kosong, dengan membakarnya, atau menyerahkan sampah yang belum dipilah pada petugas sampah/Dinas kebersihan (Pudjiastuti, Hadi \& Ilis, 2020).
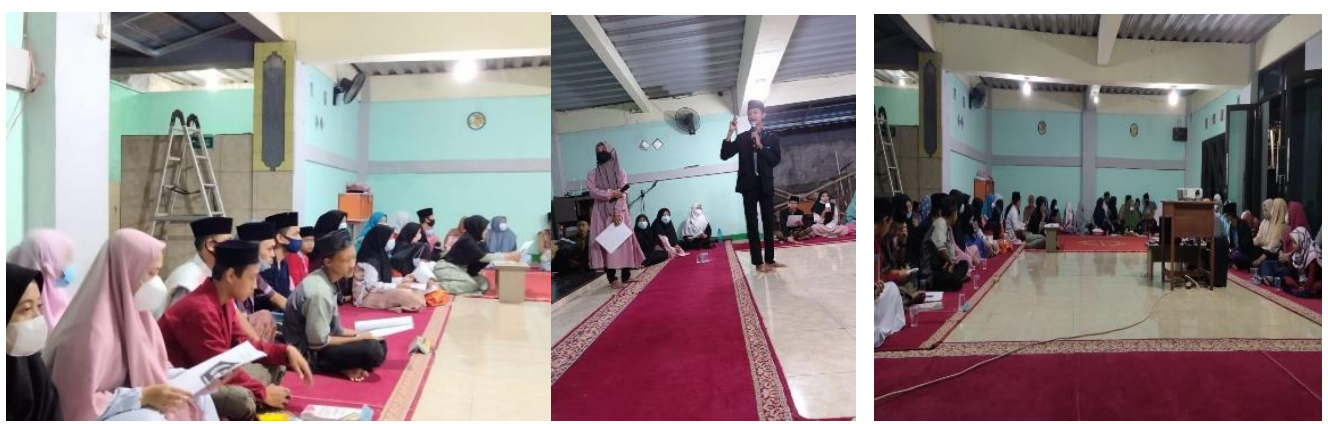

Gambar 3. Pelaksanaan Penyuluhan Pengelolaan Sampah dan Eco-Pesantren

Tahapan-tahapan pengelolaan sampah di pondok pesantren adalah:

1. Pencegahan dan pengurangan sampah dari sumbernya. Kegiatan ini dimulai dengan kegiatan pemilahan atau pemisahan organik dan anorganik dengan menyediakan tempat sampah organik dan anorganik disetiap lingkungan pesantren.

2. Pemanfaatan kembali sampah terdiri atas:

a. Pemanfaatan sampah organik, seperti komposting (pengomposan) sampah yang mudah membusuk dapat diubah manjadi pupuk kompos yang ramah lingkungan untuk melestarikan fungsi kawasan sekolah. Dengan melakukan kegiatan composting sampah organik yang komposisinya mencapai $70 \%$ dapat direduksi hingga mencapai $25 \%$.

b. Pemanfaatan sampah anorganik, baik secara langsung maupun tidak langsung. Pemanfaatan kembali secara langsung, misalnya pembuatan kerajinan yang berbahan baku dari barang bekas, atau kertas daur ulang. Sedangakan pemanfaatan kembali secara tidak langsung, misalnya menjual 
barang bekas seperti kertas, plastik, kaleng, koran bekas, botol, gelas dan botol air minum dalam kemasan.

c. Tempat pembuangan sampah akhir. Sisa sampah yang tidak dapat dimanfaatkan secara ekonomis baik dari kegiatan komposting maupun pemanfaatan sampah anorganik, jumlahnya mencapai $+10 \%$ harus dibuang ke tempat pembuangan sampah akhir (TPA) di sekolah. Selain itu untuk menciptakan suatu kondisi sekolah yang sehat, sekolah harus memenuhi kriteria, antara lain kebersihan dan ventilasi ruangan, kebersihan kantin, WC, kamar mandi, tempat cuci tangan, melaksanakan pelayanan kesehatan, pendidikan kesehatan, dan bimbingan konseling

\section{Evaluasi Pelaksanaan Pelatihan Eco-Pesantren}

Evaluasi keberhasilan pelatihan dilakukan untuk mengetahui tingkat pemahaman sebelum dilakukan pelatihan dan pada akhir dilakukan pelatihan. Evaluasi ini dilakukan untuk melihat sejauh mana keberhasilan dari pelaksanaan kegiatan yang dilakukan, sehingga dari evaluasi ini akan diketahui batas pemahaman, keterampilan peserta pelatihan, serta kegiatan apa lagi yang akan dilakukan untuk menunjang keberhasilan yang telah dicapai dan target pelatihan sesuai dengan tujuan yang telah ditetapkan. Sasaran penyuluhan dan pelatihan untuk mengingkatkan pemahaman santri tentang pengelolaan pesantren yang bersih, indah, dan asri untuk menuju sekolah yang berwawasan lingkungan. Hasil pelaksanaan pelatihan menunjukan bahwa pemahaman tentang perawatan sanitasi pesantren berkategori baik, dimana tingkat pemahaman meningkat dengan skor 78 (sedang), hal ini menunjukkan bahwa peserta pelatihan telah mengetahui tentang menjaga kebersihan pesantren, membuang sampah pada tempatnya, menjaga lingkungan pesantren tetap bersih, indah, dan asri, serta menjaga taman-taman pesantren. Sedangkan untuk aspek pengelolaan sampah pesantren tingkat pemahaman juga memiliki skor 75 (sedang) artinya peserta pelatihan sudah mengetahui tentang pengelolaan sampah pesantren, baik pengelolaan sampah organik maupun sampah anorganik. Sedangkan pemahaman tentang pengelolaan lingkungan pesantren tingkat pemahaman berskor 70 (baik) artinya peserta pelatihan sudah mengetahui beberapa cara-cara mengelola taman pesantren, menjaga kebersihan MCK, kebersihan selokan, dan mengelola sarana lain yang ada di pesantren.

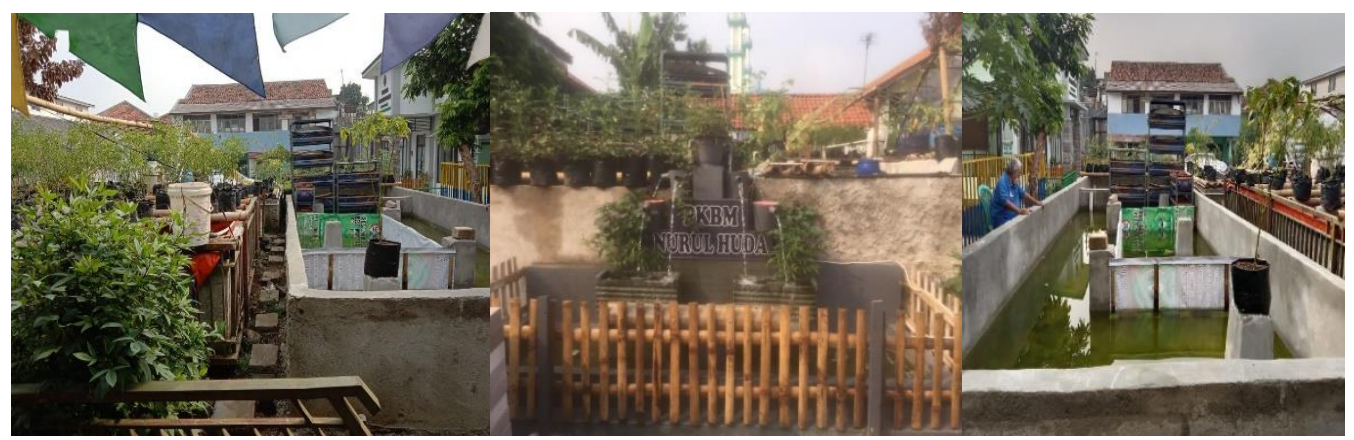

Gambar 4. Pelaksanaan Eco-Pesantren Melalui Kegiatan PKBM

(Pusat Kegiatan Belajar Masyarakat) 


\section{SIMPULAN}

Berdasarkan hasil kegiatan pelaksanaan pengabdian kepada masyarakat dapat diambil beberapa kesimpulan sebagai berikut: (1) Program pengabdian kepada masyarakat dapat dilaksanakan dan direspon dengan baik oleh warga pondok pesantren Nurul Huda, Kampung Rumbut, Cimanggis Depok; (2) Program pengabdian kepada masyarakat ini sangat bermanfaat bagi warga pondok pesantren, dan institusi pelaksana karena dapat menjadi media transfer ilmu pengetahuan dan teknologi khususnya pelestarian lingkungan hidup di pondok pesantren Nurul Huda, Kampung Rumbut, Pasir Gunung Selatan Cimanggis, Depok untuk menuju Eco- Pesantren.

\section{UCAPAN TERIMA KASIH}

Terima Kasih kami sampaikan kepada pengurus Yayasan Pondok Pesantren dan Madrasah Nurul Huda, dan para santri serta pembina yang telah memfasilitasi dan berpartisipasi aktif dalam pelaksanaan kegiatan pengabdian kepada masyarakat ini. Dengan harapan program eco-pesantren terus dapat dipertahankan dan ditingkatkan pemeliharaannya.

\section{DAFTAR PUSTAKA}

A'la, Abd. (2002). Pembaharuan Pesantren. Yogyakarta: LKiS.

Ahmadi, A., \& Uhbiyati, N. (2001). Ilmu Pendidikan. Jakarta: Rineka Cipta.

Al-Qardhawi, Y. (2002). Islam Agama Ramah Lingkungan (Ri'ayatul alBaiatu fi Syari'ati al-Islami) diterj. Abdullah Hakam Syah. Jakarta: Pustaka Al-Kautsar.

Departemen Agama RI. (1989). Al Quran dan Terjemahnya. Bandung: CV. Diponegoro.

Notoatmodjo, S. (2010). Ilmu Perilaku Kesehatan. Jakarta: Rineka Cipta.

Pudjiastuti, S. R. (2019). Metode Penelitian Pendidikan. Yogyakarta: Media Akademi.

Pudjiastuti, S. R. (2020). Improving Student (Santri) Care for the Living Environment in Nurul Huda Islamic Boarding School, Depok. JHSS (Journal of Humanities and Social Studies), 4(1), 01-04.

Pudjiastuti, S. R., \& Hadi, N. (2020). The Effect of Corona Virus on the Global Climate. JHSS (Journal of Humanities and Social Studies), 4(2), 130-136.

Pudjiastuti, S. R., Hadi, N., \& Ilis, N. (2020). The Effect of The Biopore System to Deal with Inundation at the Nurul Huda Islamic Boarding School, Cimanggis, Depok. JCE: Journal of Community Engagement, 2(01), 6-10.

Tucker, M. E., \& Grim, J. A. (2003). Agama, Filsafat dan Lingkungan Hidup (terj.). Yogyakarta: Kanisius. 